\title{
Speech act theory and \\ New Testament exegesis
}

\author{
J E Botha \\ University of South Africa
}

\begin{abstract}
Speech act theory offers New Testament exegesis some additional ways and means of approaching the text of the New Testament. This, the second in a series of two articles that make a plea for the continued utilisation and application of this theory to the text of the New Testament, deals with some of the possibilities and potential this theory holds for reading biblical texts. Advantages are pointed out and a few suggestions for the future proposed.
\end{abstract}

\section{INTRODUCTION}

As indicated in the previous article, speech act theory has to some limited extent been introduced into the reading and study of biblical texts. However, it seems that this way of approaching literature is still somewhat underutilised in New Testament studies - perhaps because the possibilities of this approach are still relatively unknown in these circles. In this article I shall try to indicate some of the possibilities this approach holds for exegesis and the reading of the text of the New Testament. It must be stressed that what follows here is only a general and exploratory depiction of what the theory has to offer exegetes, and that more definite work still needs to be done in this regard. Buss (1988:125) argues that the potential of speech act theory lies in two spheres: the theoretical reconceptualization of the process of exegesis or in terms of a refinement of exegetical procedures in their application to specific passages', and rightly remarks that these two areas cannot be strictly separated.

\section{SPEECH ACT THEORY AND NEW TESTAMENT EXEGESIS}

\subsection{The concept of utterances}

The fact that speech act theory deals with utterances rather than sentences or syntactical units provides us with a very flexible method of looking at the communication 
of the text. This is the case because an utterance, in speech act terms, can be a single word, or a phrase, or a sentence, or a pericope, or even a whole discourse or work of literature. However, the basic principles remain the same both for analysing a single-sentence utterance and for multi-sentence utterances. This can be a handy tool for biblical scholars who very often concentrate on smaller units of text for interpretations. But if the unit needs to be enlarged, it can be done without any change in the basic approach or methodology. Parts of, and the whole of a text or document can thus be studied and described in the same manner. Speech act theory also allows for the description of language on the phonetic, lexical, syntactical and pragmatic levels of language - thus a theory with diverse applications indeed.

\subsection{Importance of context}

Since it is one of the most basic principles of speech act theory that no conversation (even between implied author and reader) takes place in a vacuum, a cognisance of context is necessitated. No adequate speech act analysis is possible without establishing the context - literary, social, historical, and so on. This means that exegetes are actually forced to take the various possible contexts seriously, and to account for them in their readings of a text. This does, of course, not mean that this has not been done in the past, but the fact that this aspect is so important for a speech act reading ensures that it is not neglected. This also counters the excessive concentration on the text divorced from its various contexts, as in so-called New Criticism and French structuralism. Buss (1988:126) remarks that '[s]ome phases of biblical study, sometimes influenced directly or indirectly by this approach, similarly weakened their connection with extra-linguistic reality. These include the work now of some literary critics'. Buss, furthermore, agrees that speech act theory can be corrective in this respect.

\subsection{Verbal interaction and literary texts}

Also advantageous in a literary speech act approach to texts is the fact that this theory treats literature and literary texts the same as any other type of verbal interaction. This means that literary language can be described and defined with the same descriptive apparatus as all other types of communication. The problematic distinctions between so-called 'ordinary' and 'poetic' language are no longer valid distinctions in the study of texts (see Pratt 1977:88; see also Fowler 1977:47). This also means that because the communication in literary texts and the communication between the constructs of the texts such as the implied readers, authors, narrators, and personalities are also described and evaluated in terms of all other verbal interaction, we now have concepts and a descriptive apparatus at our disposal which was 
hitherto not fully explored in the reading of ancient texts. The interaction of concepts developed by narratology, reception theory and so on can now be further developed than was previously possible. This also means that additional extra-linguistic considerations can now be appropriated by exegetes of ancient texts, to facilitate an understanding of the communication.

\section{Rules and rule-breaking}

One of the key elements in speech act theory is the postulate that all language communication is governed by rules. Depending on the context of an utterance, certain rules come into play. These rules (also called appropriateness conditions), govern the whole of the speech situation. These concepts of appropriateness conditions 'provide a way of building into the description of an utterance the contextual norms' (Pratt 1977:87; see also McLaughlin 1984:13-29). This enables a discussion to take place regarding the dynamics of the text and its communication in terms of the way in which the author uses these rules, the deviation from or transgression of the rules, and so on, for a specific purpose. In this way, other aspects which have hitherto not played a part in the description of texts, can now be introduced to shed additional light on these texts. For instance, aspects such as 'frequency of rule violation' can now also come into play in determining style. Also important for the study of New Testament texts is the question of genre, especially in gospel studies. With the help of the concept of appropriateness conditions, genre and subgenre can be depicted as systems of appropriateness conditions, and could perhaps be useful in future descriptions of genre as this would provide avenues of viewing genre that are as yet unexplored in biblical scholarship. For a way in which a new approach to irony is possible by using these concepts, see also Botha (1989:145-153). Again, the issue of extra-linguistical matters becomes important in the sense that these appropriateness conditions are 'a crucial component of the grammar of a language even though they represent aspects of an utterance which are not part of the explicit verbal structure' (Pratt 1977:83). For Pratt this means that the one-sided concentration of Chomskyan linguistics on syntax and phonology is rectified somewhat.

\section{Personal interaction}

Speech act theory focuses on interaction on a personal level, and introduces many general principles of human (verbal) behaviour into the reading of texts. This again provides us with an arsenal of so far underutilised tools to describe the action of, for instance, the personalities in a specific situation, or the communication between implied author and readers. I have indicated (Botha 1990a) how the utilisation of speech act theory can help to solve some riddles in the text of John 4, and how John 
4:16 can be read meaningfully in speech act terms. This is an important contribution that the implementation of speech act theory can make to our exegesis of the New Testament. Leech (1983:7-17) has even divided his taxonomy of maxims/principles that govern speech situations into a level of interpersonal rhetoric and a level of textual rhetoric.

\subsection{Links with narratology}

We have already indicated that speech act theory is able to use the constructs of narratology and develop them further. But speech act theory also complements the narratological construct of the narrator in narrative texts, because concepts such as illocutionary force and implicature address additional aspects such as 'attitude', 'distance', 'affect', and 'tone', for which the formalist theories were unable to provide tools. In this regard Lanser (1981:79-80) states that other aspects such as the speaker-text relationships are made accessible by the concepts of speech act theory. She also argues that characters in the text are created by being assigned illocutionary and perlocutionary acts. In this way the so-called 'process of semantic accumulation' is in effect 'the reader's construction of a world and personae capable of "housing" the illocutionary and propositional acts which the text generates both explicitly and by implicature' (Lanser 1981:80). The fact that the methodology of speech act theory does not exclude the use of narratological concepts is very advantageous for scholars engaged in the study of narrative texts, because speech act theory does not make previous work or insights redundant, but just adds to the understanding of the texts.

\subsection{Links with reception theory}

The very important use in New Testament studies of reception theory and its implications for the interpretation of New Testament texts, are also to some extent accounted for in a theory of speech acts. The basic presupposition in speech act theory is that a person engaging in a speech act performs not only a locutionary act (producing a valid grammatical utterance) but also an illocutionary act (producing an utterance with a specific illocutionary power such as an order, a warning or a request). In addition to these two acts he/she can also perform a perlocutionary act (achieving certain effects in his/her hearers, for example, by promising he/she may be warning somebody off). The concepts of illocutionary acts and, especially, perlocutionary acts make the theory very suitable for the pretexts and principles of reception theory and offer the opportunity of including aspects of this in the description of the style of a text. Cloete (1984:9) remarks: 
Finally, there is also a perlocutive approach to, dealing with, or reading a literary work. In other words: literature is read and used with the aim of achieving a certain goal in reality, of applying it, and using it pragmatically - educationally, politically, religiously, therapeutically and so on. But the perlocution is also affixed by the reader to the work of literature or even forced upon it; to put it more clearly: the literary perlocution is an act on the part of the reader, a contribution by the reader. For literary reception-aesthetics it is an important factor to take cognisance of. (My translation of Afrikaans original.)

Patte (1988:91) furthermore argues that speech act theory and reception theory also supplement each other in the sense that the focus is on different extra-textual domains. For speech act theory the focus is on the author as producing meaning, while for reception theory the focus is on the reader producing meaning. However, it must be emphasised, as Buss (1988:126) does, that in speech act theory the perlocutionary act is also designed to achieve a certain purpose with the hearer, that is, it is goal-directed. This means that speech act theory is thus also susceptible to the precepts of reception theory.

\subsection{Between the lines}

Because speech act theory deals seriously with relationships, contexts, implied rules and rule-governed behaviour, it is able to account for aspects not specifically present in the text, but merely implied. In this regard the notion of implicature is very important. In short, implicature involves the calculations and interpretations that the hearer/reader of an utterance applies to this utterance to determine its meaning. This can happen on every level of the language, such as the levels of syntax or semantics. For instance, the grammatical construction of the ellipsis necessitates the furnishing of the referent from the context, as do certain pronouns. On the semantic level, the utterance 'You must have dinner with us!' can be understood only as an invitation and not as a command, because of the rules of implicature. This is very important for the study of texts, because speech act theory makes it possible to explain the process of how certain meanings are arrived at. This is not to say that these meanings were not arrived at previously, but speech act theory has the descriptive apparatus to describe the whole process which was previously only 'sensed' and 'intuitively felt' by literary critics. Lanser (1981:76-77) explains the benefits of this notion as the confirmation of the theory that language communicates both through and between words, and thus "provides a tool for acknowledging, naming, and studying the "gaps" in discourse - the unspoken assumptions and messages upon 
which meaning depends'. Lanser (1981:77) further argues that much of the communication of a text is not actually said or written, and this 'requires us to expand the very notion of "text" from the formalist vision of words-on-a-page to the speech act focus upon a verbal performance whose "variable meaning-potential" is determined "by specifying co-texts and contexts". This is an important insight for our dealing with biblical texts, and will help us to read responsibly 'between the lines'. (See also Patte 1988:90-91 on this aspect and the article by Du Plessis 1988 in which he attempt to clarify certain aspects of Luke 12 by implementing the notion of implicature.)

\subsection{A question of success/effectiveness}

The fact that, in speech act theory, the success of an utterance is considered to be of prime importance provides a new way of looking at a text. The fact that exegetes are now forced to also account for aspects such as the appropriateness or success or functionality of utterances in the texts and even of whole documents, necessitates the use of additional concepts, which can perhaps shed new light on the communication of texts. Even the failure of communication can be of great significance (see Botha 1990b). The style of documents can now also be expressed in terms other than those of conforming to a certain norm or model, being rigid, elevated, and so on. Terms like 'functional', 'successful', and 'appropriate' can also be shown to be relevant in a description of style - an important modification in terms of stylistics (see also Botha 1990c).

\subsection{Author's obligations}

This is also part of the fact that communication in texts is viewed in the same terms as normal verbal interaction. The literary speech situation, and its implications for the interaction between audience and authors must be taken into consideration. The demands made on the author, and how he assumes this responsibility, is an implicit aspect of the text which must not be neglected. Prologues, epilogues, asides, explanatory notes, and the way letters and argumentative texts are structured, are indications of exactly this feature. The novelty that speech act theory provides is that these aspects can now be studied from an additional vantage point - the author's obligation to his/her readers. Readers feel and expect that the writer is under an obligation to make his text worthy of their attention, and they are thus willing to allow the writer some freedom and bring their own behaviour into line with what can be expected of an audience. This is equally important for ancient texts, where the exact relationship between speaker and audience implied in a text in a specific time and context, must be determined, as must the specific rules observed in that 
context for the speaker/audience situation. Aspects such as genre and so on come into play here as well. The assumptions made by the readers (ancient and modern) at the beginning of the reading process are also important, as well as the care taken by some authors to reassure their audiences. The selection and preparation that went into the formation of the text are also important presuppositions we bring to bear when a literary work is read. These can indeed play an important part in the interpretation and reception of a text. (See Pratt 1977:116-125, 170 for an extensive discussion of this aspect.)

\subsection{Corrections to structuralism}

Patte (1988:88-90) is very positive in his evaluation of the possibilities speech act theory has to offer traditional exegesis. He even goes as far as suggesting that speech act theory presents us with the challenge of a new hermeneutical paradigm (Patte 1988:88). While both structuralism and speech act theory contend that the linguistic phenomenon can be homologated to other dimensions of human experience' (Patte 1988:89), and that the production of meaning is rule-governed, the biggest difference between the two is that, while for structural semiotics the governing rules are inscribed in the linguistic utterances, for speech act theory the rules are not inscribed in the text. These rules governing speech acts are not to be found in the text, but are extra-textual by nature. In this way speech act theory provides a welcome correction to structural analysis which demands that the meaning of the text is determined only by what is in the text.

\subsection{Religious discourses as religious acts}

Since speech act theory demands that we view all texts as acts, it follows that religious texts need to be seen as religious acts (Patte 1988:92). Although very little has been done in this respect, this way of looking at texts as acts has now presented biblical scholars with the task of accounting for the religious nature of texts in a much more systematic way. Linked to this is the great emphasis placed in speech act theory on the importance of the context of an utterance or speech act. Patte (1988:93) also raises this challenge and suggests that religious speech acts can be studied with reference to, for instance, ritual acts, because speech act theory can now provide a conceptual framework fitting for this. This is indeed a new option made possible by the introduction of speech act theory and warrants further study.

\subsection{Subjectivity and intentionality}

Because the utilisation of speech act theory necessitates the shift to a new conceptual framework (Patte 1988:94), it means that we have to look at religious discourses 
from a changed perspective, which can also involve transgressing taboos. Patte (1988:95) quotes Searle (1983:vii) and states that a speech act investigation is also based on the 'fundamental capacities of the mind [or brain] to relate the organism to the world by way of such mental states as belief and desire, and especially through action and perception' - thus proposing the utilisation of categories such as subjectivity and intentionality as a prime concern of our investigation. This is something which demands that we transgress well-established taboos in religious studies, and the other social sciences. Strange as this may seem, it is 'a neglected dimension of the meaning of religious texts and of biblical texts that speech act theory promises to help us elucidate' (Patte 1988:96). This 'shift', however, does not mean that we should fall prey to subjectivism or intentional fallacy; in the speech act paradigm categories such as intentionality and subjectivity can be studied responsibly because what is involved is rule-governed behaviour, not total subjectivism.

\subsection{New Testament form criticism and speech act theory}

Buss (1988:127) remarks that biblical studies going under the name of form criticism and speech act theory have actually come closer to each other. He even goes as far as saying that it is not impossible that Austin himself could have been influenced by biblical form criticism (Buss 1988:127-128). With regard to form criticism Buss (1988:127) refers to the work based on, for example, Tucker (1971) and Tucker \& Knierim's series The forms of Old Testament literature, and remarks that certain categories used such as genre, setting, and intention, all correspond to facets in speech act theory. For instance, there is some correspondence between the taxonomies of speech act theorists and the classifications of genre, 'intention' corresponds to some extent to Austin's illocution and perlocution, while 'setting' corresponds to speech act aspects such as contexts, mutual conceptual beliefs, and so on. From the above it is clear that research into the forms of the New Testament should indeed take a closer look at speech act theory, since the involvement can be of mutual benefit, and can so also be beneficial to exegesis.

\subsection{The future of speech act exegesis}

In his very positive evaluation of the possibilities speech act theory holds for biblical exegesis, Patte (1988:99-101) goes as far as advocating the establishment of a method of speech act exegesis. While we can only agree with him, it must be stated that we are still a long way from the general acceptance of the ideas he put forth. However, it cannot be denied that the new possibilities speech act theory has to offer need some serious consideration. Perhaps it would be prudent to take a conservative path and try to convince the sceptics by a gradual introduction of some of 
the aspects of speech act theory into practical exegesis programmes (e g Du Plessis 1988; Botha 1990a).

\section{CONCLUSION}

From the above it should be clear that a speech act theory of language presents New Testament scholarship with immense possibilities. While it is doubtful that our regular exegetical programmes will be replaced by 'speech act exegesis', there is no question that speech act theory can offer us solutions to questions more traditional approaches could not. For instance, the fact that speech act theory places the act of literary communication within the sphere of human interaction by stressing conversational rules, affords us a fresh look at what is going on in a text. The fact that the unspoken and extra-linguistic rules that also govern literary communication can now also begin to be accommodated is a giant step forward. Literary constructs, such as the implied reader and implied author, can now also be seen in this light, and some of these aspects applied to the understanding of a text. The fact that some of the concepts of speech act theory are readily compatible with other critical theories such as narrative and reception criticism, provides us with a very versatile approach which can only enhance our reading of texts in the sense that we are now able to achieve a very comprehensive reading of a text, where a number of aspects can be shown to co-exist, and co-influence the communication. In past methodologies, such a comprehensive reading of a text was much more difficult to obtain. I have also indicated that speech act theory can correct some of the precepts of structuralism, while not denying its worth. This is : very necessary correction, since in New Testament scholarship the emphasis is still to a large extent on structuralist methodologies. The basic concept of speech act theory that views human verbal and literary interaction as rule-governed behaviour makes it possible for New Testament exegetes to view various aspects such as genre, and figures of speech such as irony and rhetorical impact, in terms of the breaking of, and complying with, certain conversational and contextual rules. This has so far not been done. There are thus various ways in which speech act theory can enhance New Testament exegesis.

There is at least some indication that interest in speech act theory is growing amongst New Testament scholars. At the recent AAR/SBL National Meeting in New Orleans (17-20 November 1990) quite a number of papers were read in which speech act theory was utilised. I can only express the hope that articles such as the one by Patte (1988) and this one will stimulate the continued consideration and utilisation of speech act theory in New Testament exegesis. 


\section{Works cited}

Austin, J L [1962] 1975. How to do things with words. Oxford: Clarendon.

Botha, J E 1989. A study in Johannine style: History, theory and practice. DTh dissertation, University of South Africa.

.-. 1990a. John 4:16: A difficult text speech act theoretically revisited. Scriptura 35 (Sep), 1-9.

--- 1990b. Failure, success and speech acts in John 4:1-42: A speech act reading. Paper read at AAR/SBL Nationul Meeting, New Orleans, November 1990.

--- 1990c. Style, the language of the New Testament, and speech act theory. Paper read at the SBL International Meeting, August 5-8 1990, Vienna.

Buss, MJ 1988. Potential and actual interactions between speech act thoery and biblical studies. Semeia 41, 125-134.

Cloete, T T 1984. Taalhandelinge en die literatuur, in Van Coller, H P \& Van Jaarsveld, G J (reds) 1984:1-14.

Du Plessis, J G 1988. Why did Peter ask his question and how did Jesus answer him? or: Implicature in Luke 12:35-48. Neotestamentica 22, 311-324.

Fowler, R 1977. Linguistics and the novel. London: Methuen.

Lanser, S S 1981. The narrative act: Point of view in prose fiction. Princeton: Princeton University Press.

Leech, G N 1983. Principles of pragmatics. London: Longman.

McLaughlin, M L 1984. Conversation: How talk is onganized. Beverly Hills: Sage.

Patte, D 1988. Speech act theory and biblical exegesis. Semeia 41, 85-102.

Pratt, M L 1977. Towards a speech act theory of literary discourse. Bloomington: Indiana University.

Searle, J R 1983. Intentionality. Cambridge: Cambridge University Press.

Tucker, G M 1971. Form criticism of the Old Testament. Philadelphia: Fortress.

Van Coller, H P \& Van Jaarsveld, G J (reds) 1984. Woorde as dade: Taalhandelinge en letterkunde. Durban: Butterworth. 